\title{
„Poleszuk” nieoswojony. Wokół funkcji chłopskości w konstruowaniu polskości
}

Anna Engelking 


\section{„Poleszuk" nieoswojony. Wokół funkcji chłopskości w konstruowaniu polskości}

\section{Anna Engelking}

TEKSTY DRUGIE 2017, NR 6, S. 68-94

DOI: $10.18318 /$ td.2017.6.5

Bez chama nie byłob pana.

Przysłowie poleskie ${ }^{2}$

W [...] społeczeństwach o typie kastowym [...] świat stereotypów, wyobrażeń, mitów i legend grupowych jest względnie stały i niezmienny. [...] Analizując je, pragniemy poznać, [...] w jakim stopniu sankcjonują i usprawiedliwiają ten system.

Józef Obrębski ${ }^{3}$

1 Niniejszy artykuł jest trzecim odcinkiem cyklu, w którym analizuję wizerunek "Poleszuka" w polskim XIX- i XX-wiecznym dyskursie etnograficznym i popularnym (por. A. Engelking „Poleszuk” $w$ dyskursie ludoznawczym. Szkic do obrazu na podstawie "Ludu" Kolberga, w: Ja daję właśnie materiał... O dziele Oskara Kolberga w dwusetna rocznicę/ego urodzin, red. E. Antyborzec, Instytut im. Oskara Kolberga, Poznań 2015, s. 195-210; A. Engelking „Poleszuk” odczłowieczony. O relacji polsko-poleskiej przez pryzmat mitu [w druku]).

C. Pietkiewicz Kultura duchowa Polesia Rzeczyckiego. Materjały etnograficzne, TNW, Warszawa 1938, s. 383.

3 J. Obrębski Legenda leśnych ludzi, w: tegoż Polesie.Studia etnosocjologiczne, t. 1, oprac. A. Engelking, Oficyna Naukowa, Warszawa 2007, s. 436.

\section{Anna Engelking -}

dr hab., prof. Instytutu Slawistyki PAN, członkini TNW i KNE PAN. Etnografka, antropolożka, historyczka etnologii. Prowadzi badania terenowe na Białorusi i Ukrainie. Ostatnio opublikowała: Kołchoźnicy. Antropologiczne studium tożsamości wsi białoruskiej przełomu XXiXXI wieku (2012). Kontakt: engelking@ ispan.waw.pl 


\section{Poleska dzicz i polskie oazy}

Rozpocznę cytatem, który pochodzi z pierwszej połowy XIX wieku i odnosi się do wydarzeń z roku 1790:

$[\mathrm{P}]$ rzechodziliśmy [...] miejsca w lasach pierwotnych, gdzie ledwo co mil kilka jakaś wioseczka, a czasem tylko karczemka licha widzieć się dała. Wieśniacy tych małych osad tak byli dzicy, że za zbliżeniem się naszem z żonami i dziećmi uciekali do lasów, a my najczęściej do pustej wchodziliśmy osady. Dopiero później, wabieni darami, a szczególniej wódką, wracali pojedyńczo do domów. ${ }^{4}$

Gdzie jesteśmy? Symbolicznie bez wątpienia w dyskursie kolonialnym, skoncentrowanym wokół ambiwalentnej figury „dzikusa”, ale geograficznie? W automatyczne skojarzenie z Afryką czy Ameryką wprowadza niejaki dysonans wzmianka o "karczemce”; i rzeczywiście, autor opisuje wydarzenia rozgrywające się w Rzeczypospolitej, dokładniej - nieco na północ od Kijowa. Cytat ten pochodzi z Pamiętnika generała Jana Weyssenhoffa i odnosi się do odbytego przez 8 pułk piechoty litewskiej marszu na Ukrainę, którego powodem, według sformułowania autora, „były wieści, jakoby na kozaczyźnie gotowała się nowa wyprawa na rzeź do Polski, jaką była Humańska", natomiast celem - „dać odpór i zniszczyć ten tłum, któryby się, uzbrojony nożami, wylał na naszą ziemię"5.

Dyskurs kolonialny splata się tu ściśle ze społeczno-kulturowym kontekstem: etnokastową dychotomią, w którą wpisana jest przemoc. Czy zastosowana przez poleskich chłopów - kulturowych pobratymców owej mającej rżnąć Polaków „kozaczyzny"6 - wypróbowana strategia chowania się przed wojskiem w lesie może w tych okolicznościach dziwić? Prędzej dziwić mogłaby, choć nie powinna, skala dystansu społecznego, a co za tym idzie, symbolicznego, jaki dzieli przedstawiciela możnowładztwa i zarazem oficera polskiego wojska od poleskich chłopów. Chłopi - pierwotni, dzicy, podlegający wabieniu jak zwierzyna łowna, a więc poddani dyskursywnej animalizacji - reprezentują tu przeciwstawny wobec „poczciwego kmiotka” topos

4 J. Weyssenhoff Pamiętnikgenerała Jana Weyssenhoffa, wydałJ. Weyssenhoff, Gebethner i Wolff, Warszawa 1904, s. 17.

5 Tamże, s. 16.

6 O ambiwalencji polskiego obrazu Kozaka pisze Maria Janion, por. M. Janion Niesamowita Słowiańszczyzna. Fantazmaty literatury, Wydawnictwo Literackie, Kraków 2007, s. 167-169. 
„złego dzikusa”: negatywny biegun polskiego dyskursu o „chłopie”, który jak pokazało już wielu badaczy, konstruuje swój obiekt jako „wewnętrznego obcego"8. Myśl o włączeniu pańszczyźnianych chłopów znad Prypeci do kategorii "swoich" nikomu nie przychodzi do głowy. Byłaby zbyt obrazoburcza. Nawet Kościuszko, sam pochodzący z Polesia i znający mieszkańców tamtejszej wsi z doświadczenia jej hierarchiczno-symbiotycznej relacji z dworem, by wyrazić ideę uobywatelnienia chłopów, symbolicznie przyoblecze się nie w świtkę Poleszuka, ale w sukmanę Krakowiaka. To bowiem Krakowiak, emblematyczny reprezentant mitu chłopa-Piasta', jako "gwarant prapolskich wartości"10 uosabia przeradzający się w naród „lud polski”.

Wrogi dystans klasowy i kulturowy uwypukla Weyssenhoff dodatkowo, ujawniając zaskoczenie przyjęciem, jakie zgotował wojsku przedstawiciel jego własnej klasy społecznej i zarazem pan zbiegłych do lasu chłopów: „w porządnym murowanym domu, sam ubrany w mundur nasz generalski. [...] Wśród takiej pustyni i dziczy zadziwiły nas niemało i mieszkanie, i przyjęcie, i postać pana Oskierki"11. Dostrzeżony przez autora skrajny kontrast między przepychem pańskiego dworu i wegetującą w materialnej nędzy pańszczyźnianą wsią, sytuowany w konceptualnej ramie opozycji kultura - brak kultury, zostanie uznany w latach 40. XX wieku przez antropologa Józefa Obrębskiego za najbardziej krańcowy przypadek dychotomicznej struktury społecznej „dawnej, późniejszej i nawet obecnej” Polski². O Polesiu, „kraju królewiąt i mużyków", Obrębski napisze:

7 Jego wersję etnograficzną Zbigniew Libera nazwał "fikcją ludoznawczą", por. Z. Libera Lud ludoznawców: kilka rysów do opisania fizjonomii i postaci ludu naszego, czyli etnograficzna wycieczka poXIX wieku, w: Etnologia polska między ludoznawstwem a antropologiq, red. A. Posern-Zieliński, KNE PAN, Poznań 1995, s. 137-152.

8 Jako pierwsi na ten temat pisali Ludwik Stomma i Stanisław Węglarz, por. L. Stomma Antropologia kultury wsi polskiejXIX wieku, Instytut Wydawniczy PAX, Warszawa 1986; S. Węglarz Chłopi jako "obcy". Prolegomena, w: Pożegnanie paradygmatu? Etnologia wobec współczesności, red. W.J. Burszta, J. Damrosz, Instytut Kultury, Warszawa 1994, s. 78-101.

9 Por. E. Korulska O chłopie - bez tytułu, "Polska Sztuka Ludowa. Konteksty” 1994 nr 3-4, s. 127-128; Z. Libera Lud ludoznawców, s. 145-147.

D. Simonides Folklorystyka wobec mitologizacji politycznej w pierwszej połowieXIX wieku, w: Polskie mity polityczne XIX i XX wieku, red. W. Wrzesiński, Wydawnictwo Uniwersytetu Wrocławskiego, Wrocław 1994, s. 71.

11 J. Weyssenhoff Pamiętnik generała Jana Weyssenhoffa, s. 16-17. 
Dwuwarstwowość społeczeństwa polskiego i pańskość jego inteligencji nigdzie nie uzyskała równie silnych i ostro zarysowanych konturów, aniżeli na rozległych obszarach polsko-ruskiego pogranicza, przede wszystkim zaś na Polesiu. Polskość miała tu tylko pańskie rodzime tradycje, pańską przeszłość. Ostrość podziału klasowego potęgowała odrębność etniczna miejscowych chłopów ruskich. [...] W warunkach poleskich klasowa megalomania miejscowej sfery polsko-pańskiej, jej władcza postawa wyższości i ostentacyjnej pogardy dla chama-mużyka, były - wobec wewnętrznej niejednolitości kulturalno-obyczajowej tej strefy - najważniejszym znamieniem przynależności klasowej, manifestacją własnej pozycji społecznej i mającym nieomal charakter obowiązku moralnego wyrazem solidarności grupowej. ${ }^{13}$

Ta diagnoza, uświadamiająca ścisły związek stereotypu Poleszuka-dzikusa, czyli nieczłowieka, ze strukturą społeczną Polesia i zarazem z podstawową kategorią organizującą mit kresowy, jaką jest odpowiadająca relacji dominacji/podporządkowania symboliczna opozycja wyższość - niższość ${ }^{14}$, ma istotne znaczenie dla pytania o funkcję poleskości w konstruowaniu polskości.

Na obraz poleskiego chłopa, jaki zarysował Weyssenhoff - uosabiający prototypową, pańską polskość ziemianina i żołnierza-patrioty - składają się egzotyzujące i zarazem deprecjonujące koncepty pierwotności, dziczy i pustyni. Odnoszą się one zarówno do obserwowanego kraju, jak i do jego mieszkańców; dotyczą krajobrazu przyrodniczego, kulturowego i cywilizacyjnego. Domeną półzwierzęcych istot bytujących w lesie jest pustynia cywilizacyjna będąca zarazem dżunglą - sfera usytuowana poza granicami definiowanego przez „kulturę” świata ludzkiego. Ludzkiego i zarazem polskiego. Jego jedyną wyspę w tej dziczy - oazę ${ }^{15}$ kultury, ściślej: kultury polskiej - stanowi murowany dom, czyli pałac, pana Oskierki.

13 J. Obrębski Pańska szkoła i mużyckie dzieci, tamże, s. 353.

14 „Podstawowym mitu tego składnikiem jest poczucie polskiej wyższości na Wschodzie oraz pełnionego tu posłannictwa cywilizacyjnego i religijnego. Najsilniej zaznaczyły one swą obecność w wyobraźni i dążeniach Polaków w XIX i XX wieku" (M. Janion Niesamowita Słowiańszczyzna, s. 172). Szerzej na temat mitu kresowego, z odwołaniami do Daniela Beauvois, zob. tamże, s. 165-176. Dychotomiczną wizję pionowego uwarstwienia klas społecznych i jego mityczne legitymizacje analizował Stanisław Ossowski, por. S. Ossowski Struktura klasowa w społecznej świadomości, w: tegoż O strukturze społecznej, PWN, Warszawa 1986, s. 120-124.

15 Polski dyskurs kresowy pokazuje, że owa oaza jest w istocie twierdzą, otoczoną przez morze wrogiego i groźnego barbarzyństwa. Z takich twierdz-stanic składa się przedmurze. 
Polski dyskurs kolonialny ani się od generała Weyssenhoffa nie zaczął, ani tym bardziej na nim nie skończył. Zaprezentowana tu próbka dotyka istoty polskiego postrzegania zamieszkujących pogranicze Białorusi i Ukrainy chłopów: niekatolickich (ruskich, czyli prawosławnych bądź unickich, zależnie od okresu historycznego) i niepolskojęzycznych (mówiących białorusko-ukraińskimi dialektami). Tworzony w obrębie polskiej kultury prawomocnej dyskurs o Poleszuku, którego metryka jest dawna, a mutacje ciągle żywotne, jest kolonialny, klasowy i nacjonalistyczny na równi. Płynnie przechodzi od fazy przednowoczesnej do nowoczesnej, z jej ideologią modernizacji i kategoryzacjami rasowymi.

\section{Istota bez kultury}

Sięgnijmy po przykłady tego dyskursu z dwudziestolecia międzywojennego, kiedy to chłopi zamieszkujący zachodnie Polesie byli obywatelami państwa polskiego, formalnie pełnoprawnymi. W renomowanym czasopiśmie krajoznawczym „Ziemia” Michał Marczak, autor popularnego przewodnika turystycznego po Polesiu, zamieścił artykuł Ze spostrzeżeń nad Poleszukami. Czytamy w nim m.in.:

[J]est to obszar samych sprzeczności. W praktyce uznaje się tu hierarchiczność i różnice społeczne, wrodzony konserwatyzm nie pozwala na zmianę, apatja i rezygnacja wobec przemożnych sił przyrody wykluczają wszelką próbę wyłamywania się. Obok punktów, nacechowanych wysoką kulturą i gustem warstw wyższych widzi się na każdym kroku niesłychany prymityw, niepodlegający w najmniejszym stopniu jakiemuś wpływowi i niedający się podciągnąć. I tak zawsze było. ${ }^{16}$

Pozostając w paradygmacie hierarchicznej i korelatywnej klasowo-narodowej opozycji17 polskości i poleskości, w której ta pierwsza ucieleśnia szlachectwo kulturowe, druga zaś jest nie tylko nosicielką piętna, ale także winy za ów stan rzeczy, Marczak tworzy tu nieco bardziej złożony niż Weyssenhoff wizerunek Poleszuka. Jego „Poleszuk”, skonstruowany jako esencjalistyczny typ, konsekwentnie reprezentuje negatywny, stygmatyzujący biegun dyskursu o „chłopie”. Na mocy swojej „wrodzonej”, inaczej „odwiecznej” natury ma 
on nie tylko zwierzęce cechy dzikusa, których sygnałem jest etykieta „niesłychany prymityw". Brak mu także inicjatywy, inteligencji, energii, impulsów twórczych; jedyną chyba jego ludzką cechą jest presuponowany przez autora upór. Chociaż nie. Upór wszak cechuje bydło robocze - woły, tradycyjną siłę pociągową na Polesiu i zarazem emblemat stosunków pańszczyźnianych ${ }^{18}$. Apatyczny i bierny wobec przyrody, konserwatywny i konformistyczny wobec społeczności, uparcie oporny wobec starań, by na niego „wpłynąć" i go "podciągnąć”, wytworzony przez Marczaka „Poleszuk” komunikuje: taka moja natura, zatem nie można mnie zmienić. Zaskoczenie? W żadnym wypadku. „Jakkolwiek bądź - Poleszuk stanowi osobliwy, zupełnie odrębny typ, jest - Poleszukiem"19.

Zanim zapytamy, co się kryje w figurach „wpływu” i „podciągania”, pójdźmy tropem pierwszego polskiego dekonstruktora mitu Poleszuka. Mam na myśli wspomnianego już Józefa Obrębskiego, przedwojennego badacza Polesia, którego nieznane wcześniej pisma z lat 30. i 40. ukazały się w moim opracowaniu naukowym ${ }^{20}$. Na jego prekursorstwo w zakresie polskiej krytyki postkolonialnej jako pierwsza zwróciła uwagę Grażyna Borkowska" ${ }^{21}$, wskazując że demaskował on „pseudowiedzę o polskich kresach, propagowaną przez aparat władzy w latach dwudziestych i trzydziestych, a mówiąc językiem Saida - kolonizacyjny dyskurs władzy"22.

Obrębski przyglądał się krytycznie obfitej i bardzo poczytnej w latach 30. publicystyce i literaturze popularnonaukowej dotyczącej Polesia, nie tracąc z oczu także ikonografii. Konstatując „pseudoobiektywny, quasi-krajoznawczy, semiinformacyjny i jakoby etnograficzny charakter tego typu produkcji",

18 Na ten temat piszę w artykule: A. Engelking „Poleszuk” odczłowieczony. O relacji polsko-poleskiej przez pryzmat mitu [w druku].

19 F.A. Ossendowski Polesie, Wydawnictwo Polskie R. Wegner, Poznań [1934], s. 19.

20 J. Obrębski Polesie. Studia etnosocjologiczne, t. 1, oprac. A. Engelking, Oficyna Naukowa, Warszawa 2007.

21 Zob. G. Borkowska Daleko od mitu. Kresy według Obrębskiego, „Prace Filologiczne. Seria Literaturoznawcza" 2008 t. 55, s. 123-130; G. Borkowska Perspektywa postkolonialna na gruncie polskim. Pytania sceptyka, "Teksty Drugie" 2010 nr 5, s. 40-52.

G. Borkowska Perspektywa postkolonialna, s. 51. Borkowska konstatuje m.in.: „Refleksja Obrębskiego łączy dwie sfery rzeczywistości, w innych dyskursach rozdzielane: radykalizm społeczny i nostalgiczne przywiązanie do polskiej kultury szlacheckiej. Badacz pokazuje nieredukowalny związek między nimi, sprzęgnięcie przemocy i mechanizmów kulturotwórczych. [...] Obrębski nie posługuje się metaforą, nazywa rzeczy po imieniu, bezwzględnie rozprawia się z kresowym mitem" (tamże, s. 49-50). 
wskazywał, że stanowi ona „literacki montaż sentymentów społecznych"23. Niestety nie ukończył rozpoczętego studium Legenda leśnych ludzi, którego jedna z części miała nosić tytuł Mit Poleszuka. Dysponujemy więc tylko materiałami warsztatowymi tego projektu: garścią konspektów, notatek i ułamków tekstu ${ }^{24}$.

Wśród nich znajduje się także egzemplarz cytowanego artykułu Marczaka. W komentarzu na marginesie Obrębski punktuje, że autor w odniesieniu do przedstawianego podmiotu nie użył słowa człowiek. Poleszuk to dla Marczaka istota. Uczony wypisał też z tekstu cytaty ${ }^{25}$, które włączył do konspektu "Polski" wizerunek Poleszuka. Wizerunek ten w jego ujęciu przedstawia się lapidarnie: „typ fizyczny: nieokreślony, konstytucja: chorowita, cechy psychiczne: ujemne”. Z kolei w konspekcie Wyobrażenia popularne o „kulturze” kresowej wymienił m.in.: brak kultury, komunizm rodzinny, poniżające stanowisko kobiety, przesądność i zabobonność, brak prawdziwej religijności, dzikość i zbrodniczość, promiskuityzm płciowy, pijaństwo, hipokryzja (fałszywość ludu, mówiącego jedno, robiącego drugie), lenistwo i niezaradność, konserwatyzm, brak szerszych zainteresowań ${ }^{26}$. Wskazany przez Obrębskiego konstytutywny paradoks polegający na tym, że kultura polska definiuje kulturę chłopskich mieszkańców Polesia przez brak kultury ${ }^{27}$, a określając ich samych, unika słowa $c z ł o w i e k^{28}$, wystarcza już do wyciągnięcia wniosków co do istoty

J. Obrębski Legenda leśnych ludzi, s. 438.

Większość tego materiału ukazała się drukiem jako: J. Obrębski Legenda leśnych ludzi.

„Apatyczna, nieskora do wybuchu ludność, o cerze bladej, szatynowym uwłosieniu, wzrostu średniego". „Okrutna, macosza przyroda [...] dziesiątkuje ludność już w zaraniu życia, gnębi ją chorobami nagminnymi, wśród których króluje kołtun, a asystuje mu reumatyzm, malaria i gruźlica”. „Przyroda spaczyła charakter tubylca, stępiła umysłowość, wyposażając jedynie w świetny wzrok i doskonały słuch”. „Kieszonkowa lampka elektryczna u nauczyciela budzi podziw i lęk u tubylców" (M. Marczak Ze spostrzeżeń nad Poleszukami, s. 134-135).

6 J. Obrębski Legenda leśnych ludzi, s. 439-440.

7 Jak pokazał Bourdieu, perspektywa szlachectwa kulturowego wyklucza inne niż własna definicje kultury i jest narzędziem - przez mechanizm uszlachetniania i piętnowania kulturowego wytwarzania hierarchii klas i kategoryzowania narodowego.

Przeprowadzona przeze mnie analiza artykułu Marczaka pod kątem leksyki potwierdza, że nie występuje w nim jednostka człowiek/ludzie. Autor posługuje się typizująco-reifikującymi singulariami: Poleszuk, istota, tubylec, autochton, poleski chłop, a także rzeczownikiem zbiorowym ludność. Przymiotnik ludzki notuje jedno użycie, przy czym jego kolonialny kontekst jest aż nadto widoczny: „[Z]miana charakteru Polesia jest nieunikniona, przyjść musi i rezerwatu ludzkiego nikt nie będzie tworzył" (M. MarczakZe spostrzeżeń nad Poleszukami, s. 132). 
konstruowanego w ten sposób wyobrażeniowego rewersu: autowizerunku Polaka. Już generał Weyssenhoff zademonstrował, że tylko Polak dysponuje kulturą, ergo jest człowiekiem.

Oddajmy głos Obrębskiemu:

[M]ożemy się pławić $\mathrm{w}$ dotychczasowych popularnych przesądach; Poleszuk może być dla nas tym słomianym chochołem czy małpoludem, którego zeń robimy. [...] Poprzez obraz, który tworzymy o nim, na jego temat i jego kosztem, nie oddajemy [bowiem] jego rzeczywistości, lecz stwarzamy wierne - nieuświadomione [...] i dlatego właśnie wierne - odbicie i wizerunek siebie samych, takich jakimi współcześnie jesteśmy. ${ }^{29}$

\section{Prasłowiański Pigmej}

"Jeśli ten obraz waha się między chochołem i małpoludem - czyż Poleszuk ponosi zań odpowiedzialność?" - spuentował swój wywód Obrębski ${ }^{30}$.

Żaden z użytych tu epitetów nie jest przypadkowy. Chochoł/Chach'ot to etnonim przezwiskowy powszechnie odnoszony do użytkowników dialektów ukraińskich i języka ukraińskiego ${ }^{31}$. Pełni bądź neutralną funkcję sygnalizowania zróżnicowań etnicznych (z perspektywy użytkowników lokalnych dialektów), bądź - z hegemonicznej perspektywy kultur dominujących: rosyjskiej i polskiej - służy piętnowaniu ruskojęzycznych chłopów/Ukraińców. Jego etymologia, zgodnie z uniwersalnym mechanizmem tworzenia nazw grup etnicznych od cech wyglądu zewnętrznego, wiąże się z charakterystyczną fryzurą: włosami zebranymi w sterczący czub (pęk, kitkę) ${ }^{32}$. Dla polskiego odbiorcy ta motywacja semantyczna jest nieczytelna; polski chochoł jest słomiany i ewokuje skojarzenie z Weselem Wyspiańskiego. A także ze „słomą z butów", przypisywaną jednostkom wykluczanym/piętnowanym przez grupę asymilującą. Poleszuk jako słomiany chochoł to nikt inny, tylko prymitywny, ciemny cham, któremu z natury nie jest dostępna prawdziwa kultura.

29 J. Obrębski Legenda leśnych ludzi, s. 443.

30 Tamże.

31 Stąd określenie język chachłacki.

32 W. Boryś Słownik etymologiczny języka polskiego, Wydawnictwo Literackie, Kraków 2005, s. $63-64$. 
A Poleszuk jako małpolud? Zza figury małpoluda wyłania się nowoczesne przetworzenie motywu dzikusa/dziecka natury: obecna w kulturze popularnej od drugiej dekady XX wieku opowieść o „człowieku-małpie”, czy też „królu małp" - Tarzanie ${ }^{33}$. Obrazy i tropy tej opowieści, jak również Księgi dżungli Kiplinga, obu szeroko znanych w wersjach literackich i filmowych, współgrały z żywą w zbiorowej wyobraźni figurą Poleszuka-dzikusa, więcej: zostały utrwalone we frazematyce w postaci określania Polesia mianem polska dżungla ${ }^{34}$, a jego mieszkańców - leśni ludzie $e^{35}$. Egzotyzujące i paternalistyczne wyrażenie leśni ludzie obsługiwało też modernizacyjny aspekt kolonialnego dyskursu o Poleszuku³; Obrębski dostrzegał jego symboliczny potencjał, skoro swoją krytyczną analizę tego dyskursu zatytułował właśnie Legenda leśnych ludzi.

W pliku materiałów uczonego, sygnowanych $L L L$ [Legenda leśnych ludzi], znalazłam luźną kartkę ze złożoną z dwóch wyrazów zapiską: „pigmeizowanie Poleszuka"37. Trafności zawartego w tej formule spostrzeżenia, odnoszącego się do strategii dyskursywnych, które dziś nazywamy egzotyzacją, nie sposób zanegować, gdy czyta się enuncjacje autorów, jak ujmował to Obrębski, „literatur[y] propagandow[ej] [...] charakterystyczn[ej] dla współczesnej mitotwórczości" ${ }^{38}$. Oto dla przykładu charakterystyczna próbka pióra łódzkiego dziennikarza Wacława Pawlaka:

Autorem cyklu powieści o Tarzanie był amerykański pisarz Egdar Rice Burroughs; kolejne tomy ukazywały się w latach 1912-1965. Początek ekranizacji cyklu to film Człowiek-małpa z 1932 roku.

Wystarczy przypomnieć tytuł popularnej powieści dla młodzieży autorstwa Ferdynanda Antoniego Ossendowskiego W polskiej dżungli (1935).

35 To określenie zyskało popularność dzięki rozgrywającej się w lasach Polesia powieści Marii Rodziewiczówny Lato leśnych ludzi (1920); przy czym sama powieść jest zbudowana na innej topice niż stereotypizacja Poleszuka. Rodziewiczówna odwołuje się do ideologii skautowskiej, polskiego mitu narodowego i wyidealizowanego obrazu "dziecka natury" w kontraście wobec cywilizacji.

Dla przykładu: Ksawery Pruszyński w reportażu Kiełkowanie na bagnie użył tego wyrażenia kilkakrotnie; też: leśni ludzie z rojst (K. Pruszyński Kiełkowanie na bagnie, w: tegoż Podróż po Polsce, Towarzystwo Wydawnicze „Rój”, Warszawa 1937, s. 108). Notatka ta nie znalazła się w opracowanym przeze mnie tomie pism poleskich J. Obrębskiego Polesie. Studia etnosocjologiczne, t. 1.

38 J. Obrębski Legenda leśnych ludzi, s. 438. Jedną z inspiracji krytycznego konceptu „pigmeizowania Poleszuka" musiał być dla Obrębskiego reportaż Pruszyńskiego Kiełkowanie na bagnie, zamieszczony w „Wiadomościach Literackich” 16 sierpnia 1936 roku (tu cytuję za zbiorowym 
Tuż za linją środkowego Bugu [...] poczyna się kraina [...] wyglądem swym i prymitywem życia jej mieszkańców żywo przypominająca egzotyczne zakątki świata. [...] Poleszuk [...] jest unikatem na naszych ziemiach i egzotykiem. Żyje on w warunkach najbardziej pierwotnych. ${ }^{39}$

Podobne zabiegi retorycznej egzotyzacji nie tylko odsyłają do zanimalizowanej figury egzystującego w zbieracko-łowieckiej gromadzie, pogrążonego w niedorozwiniętym kulturowo świecie prymitywnych wierzeń mieszkańca dżungli. Poleszuk, „leśny człowiek” z piętnem Pigmeja, czyli polski wewnątrzkolonialny wariant dzikusa, jest zarazem reprezentantem polskiej odmiany dyskursu rasowego. Czy raczej: rasistowskiego.

Zaproponowany przez Obrębskiego koncept pigmeizacji nie tylko nawiązuje do mitologemów z opowieści o nowoczesnym dzikusie-małpoludzie (negatywnymi bohaterami cyklu o Tarzanie byli krwiożerczy Pigmeje ${ }^{40}$ ). Wiąże się też z jednym z centralnych pojęć teorii rasowych z początków XX wieku, jakim była mongolizacja ${ }^{41}$. Dyskurs rasowy, funkcjonujący podobnie jak kolonialny w konceptualnej ramie cywilizacyjnej wyższości Zachodu nad Wschodem, oparty na hierarchii i uprzedmiotowieniu, symbolicznie wykluczający napiętnowane grupy, jako instrument nadawania piętna

wydaniem z 1937 r.); podobnie jak z tekstu Marczaka wypisywał z niego cytaty. Użyte przez Pruszyńskiego figury retoryczne to podręcznikowy przykład dyskursu modernizacyjnego, w którym wykluczenie dokonuje się poprzez egzotyzowanie (= pigmeizowanie) esencjalistycznego podmiotu zbiorowego: „Wszystko w tych rojstach było zatem jak gdzieś w Rodezji czy Kambodży, gdzie misjonarz wypłasza przedewszystkiem miejscowego czarnoksiężnika”; „Fabryka przerabia drzewo poleskie, a jako ważny «produkt uboczny» przerabia i poleskiego człowieka. Praca na starej wsi poleskiej stanowi jeszcze jedno podobieństwo z murzyńskiemi stosunkami. W swej bezwzględnej większości ciążyła na kobiecie. Wielkiem zajęciem mężczyzny były sianokosy, dokonywane na łąkach bagiennych. Wszystkie inne zajęcia należały do kobiety. Mężczyzna wiódłżywot kacyka podzwrotnikowego, polował, łowił ryby. Tłuczeniem kaszy i mieleniem zboża zajmowała się kobieta. Fabryka wszystko zmieniła" (K. Pruszyński Kiełkowanie na bagnie, s. 100, 103; podkr. - A.E.).

W. Pawlak Naród bagienny, "Kurier Literacko-Naukowy” 1937, dodatek do nru 32 "llustrowanego Kuriera Codziennego", s. VI.

Tom cyklu zatytułowany Tarzan wśród Pigmejów ukazał się po polsku w 1938 roku.

„Rasa okazała się skutecznym narzędziem do symbolicznego wykluczenia wrogich narodów z grona cywilizowanych Europejczyków. «Mongolizacja» [...] służył[a] konstrukcji bądź utrwaleniu własnej wspólnoty z pomocą przemawiającego do wyobraźni obrazu «obcego»" (M. Górny Wielka Wojna profesorów. Nauki o człowieku (1912-1923), Wydawnictwo IH PAN, Warszawa 2014, s. 214). 
stosował m.in. takie koncepty, jak mongolizacja, tataryzacja czy mulatyzacja. Odnoszono je, jak pokazał niedawno Maciej Górny, do grup etnicznych/ narodów/„ras”, stanowiących lub mogących stanowić wrogie czy konkurencyjne organizmy polityczne ${ }^{42}$. Fundamentalną rolę w procedurach stygmatyzowania i, w konsekwencji, wykluczania odgrywała w tym dyskursie również uniwersalna opozycja czysty - nieczysty/mieszany. Stąd kariera przeciwstawianych „czystości rasowej” konceptów, takich jak bastardyzacja czy nawet syfilizacja, przede wszystkim zaś teorii mieszanych, inaczej zdegenerowanych ras $^{43}$. Zgodnie z tą logiką spigmeizowany Poleszuk, jako „mieszaniec”, miałby stanowić „element bezwartościowy pod względem rasowym" 4 .

„Poleszucy ród swój wywodzą od zamieszkałych ongiś na tych ziemiach Krywiczan i Drewlan, z pewną d o mi e s z ką innych grup etnicznych" - czytamy dalej w tekście Pawlaka - „[...] Prawdopodobnie są oni mieszanym typem etnicznym, w żyłach którego płynie krew prasłowiańska, z d o mi e s zką sarmackiej i litewskiej, a może i tatarskiej ${ }^{45}{ }^{46}$. W dwudziestoleciu międzywojennym funkcjonowała na gruncie polskim klasyfikacja ras autorstwa rodzimych antropologów fizycznych, z Janem Czekanowskim na czele, zgodnie z którą Polacy mieli reprezentować „typ sarmacki" ${ }^{47}$. Niżej od niego w hierarchii stał „typ

Por. M. Górny Wielka Wojna profesorów, s. 180-204; 211-213.

Por. tamże, s. 184-187.

Logika tego myślenia, jak pokazał XX wiek, prowadzi do fizycznej eliminacji zarówno całych "zdegenerowanych ras", jak i indywidualnych „mieszańców”.

Według enuncjacji twórców dyskursu rasowego, "wielowiekowe współżycie z tatarskimi nomadami" miało odcisnąć się negatywnie zwłaszcza na Rosjanach i Ukraińcach (por. M. Górny Wielka Wojna profesorów, s. 180-185). Jak widać, koncept mongolizacji/tataryzacji dotyczył też należących do tej samej szerokiej wspólnoty etnojęzykowej mieszkańców Polesia.

W. Pawlak Naród bagienny, s. VI; podkr. - A.E. Źródłowy cytat, którym posłużył się Pawlak, pochodzi z wydanej w serii "Cuda Polski” wzorcotwórczej książki Ossendowskiego Polesie: „Prawdopodobnie - jest to mieszany typ etniczny, a w żyłach jego płynie krew prasłowiańska z domieszką sarmackiej, litewskiej i, być może, poczęści - skandynawskiej" (F.A. Ossendowski Polesie, s. 18-19). Zastąpienie Skandynawów Tatarami nie zmienia semantycznej istoty rzeczy: tak czy owak w żyłach poleskich mieszańców płynie krew dzikich najeźdźców.

7 „Typ sarmacki «który dawniej charakteryzował ową ruchliwą i bujną brać szlachecką, dziś wybija się wśród naszej inteligencji» - pisał Jaxa-Bykowski. «Pozostaje to niewątpliwie w związku z szybkim rozwojem fizycznym, ale też i tą 'okrutną fantazją rycerską', którą unieśmiertelnił Sienkiewicz w swoim literackim Kmicicu»" (M. Górny Wielka Wojna profesorów, s. 195). 
dynarski”, odpowiadający Ukraińcom, zaś „na dole polskiej hierarchii rasowej znaleźli się reprezentujący przeważnie typ prasłowiański Białorusini" ${ }^{48}$.

Poleski kolonialno-rasistowski małpolud-Pigmej okazuje się więc dzikusem prasłowiańskim, co wyjątkowo dobrze koresponduje z mitem o archaiczności Polesia. Mit ten wskazuje wąski przesmyk prowadzący do pozytywnego bieguna polskiego wizerunku Poleszuka. Wąski w istocie, ponieważ ów biegun, przypisujący poleskim chłopom charakterystyczną dla toposu arkadyjskiego "łagodność" i „dobroduszność” oraz afirmujący efektywne przystosowanie „leśnych ludzi” do otaczającej ich przyrody, ma w stosunku do negatywnego wyjątkowo nikłą reprezentację w tekstach ${ }^{49}$. Ma też ograniczenia gatunkowe: pozytywne wartościowanie archaizmów w kulturze i języku grup etnicznych Polesia funkcjonowało przede wszystkim w dyskursie naukowym, spokrewnionym z romantycznym mitem folkloru jako „skarbca narodowości"50. W dyskursie popularnym wszystko, co uchodziło za przeżytki „prasłowiańskiej” przeszłości, traktowano z zasady jako przesąd i zabobon, a więc to, co w myśl sprymitywizowanego projektu oświeceniowo-pozytywistycznego należało ze wsi wykorzeniać.

Dla uzasadnienia niższości intelektualnej „typu prasłowiańskiego” dyskurs rasowy przywoływał autorytet nauki: „Z badań polskich antropologów wynikało, że w szkołach II Rzeczypospolitej procent przedstawicieli tego typu malał wraz z każdym rokiem edukacji" ${ }^{\text {"1 }}$. Legitymizowana przez obiektywizujący idiom naukowy teza o związku „rasy” i zdolności intelektualnych usuwała z pola widzenia przemoc polskiej grupy dominującej wobec podporządkowanych jej ruskich chłopów. Dokonywała tego, naturalizując przekonanie o ciemnocie Poleszuków/Białorusinów: jako cecha biologiczna czyniłaby ich „z natury" (a nie w wyniku oddziałujących przez stulecia systemowych uwarunkowań społeczno-kulturowych, ekonomicznych i politycznych) niepredysponowanymi do edukacji szkolnej. „Na abstrakta jest za tępy i leniwy. Taka już jego natura, prawosławie zaś nie było i nie jest zdolne do

48 M. Górny Wielka Wojna profesorów, s. 195-196. Autor dopowiada: „Co prawda Czekanowski zdecydowanie krytykował wszelkie próby utożsamiania typów rasowych z narodowościami, ale jego trójpodział w znacznym stopniu pokrywał się z trzema narodowościami II Rzeczypospolitej: Polakami, Ukraińcami i Białorusinami" (tamże, s. 195).

Por. A. Engelking „Poleszuk” w dyskursie ludoznawczym, s. 198, 204-207i „Poleszuk”odczłowieczony. 
wytworzenia i utrwalenia w umyśle pierwotnym pojęć oderwanych"52. W pakiecie z naturalną niepełnosprawnością intelektualną (zwierzę!) otrzymujemy jeszcze prawosławie: podręcznikowy przykład dyskursu orientalizującego niepolskich mieszkańców wschodu Rzeczypospolitej. Podważenie dogmatu o wyższości cywilizacji zachodniej, tu: polskości, nikomu nie przychodzi do głowy.

Tak oto zataczamy koło i wracamy do „żyjącego w stanie natury”, ergo pozbawionego umiejętności myślenia (podobnie jak kobieta) dzikusa. Czy Pigmeja; na jedno wychodzi. Do zaiste „pełnej i idealnej antytezy"53 cywilizowanego, oświeconego i kulturalnego Polaka, czystego rasowo Sarmaty.

\section{Ruski dzikus bolszewik}

Usytuowanie Poleszuka/Białorusina na najniższym szczeblu polskiej hierarchii "ras” jest motywowane również - o ile nie przede wszystkim - logiką dyskursu nacjonalistycznego. Deprecjacja poleskiej „prasłowiańskości” wynika wszak z tego, że jest to prasłowiańskość ruska, nie polska (jaką była choćby ta fantazmatyczna, ideologicznie antyniemiecka, wiązana z odkrytą w latach 30. osadą kultury łużyckiej w Biskupinie). Ale co tam prasłowiańskość! To współczesna, nieusuwalna ruskość Poleszuka, postrzegana przez okulary antyrosyjskości i antykomunizmu - ideologicznych konstruktów konstytuujących polskość - jest sednem problemu, jaki z oswojeniem go (inaczej: „asymilacją") ma polska kultura dominująca.

Pisze Stanisław Tołpa, botanik, badacz torfowisk: „Od szeregu tygodni stykałem się z ciemnym biednym ludem poleskim, który, wciśnięty między wodę, bagno i wydmę piaszczystą, pędzi żywot zupełnie pierwotny, na pół dziki. W takim zacofaniu kulturalno-życiowym otrzymaliśmy go od Rosji"54. Ciemny prasłowiański dzikus okazuje się oto dzikusem zrusyfikowanym. I demonstruje nowe oblicze: grymas dzikiej, barbarzyńskiej i odwiecznie wrogiej Polsce, esencjalistycznej Rosji ${ }^{55}$.

\section{Marczak Ze spostrzeżeń nad Poleszukami, s. 135.}

J. Obrębski Polesie archaiczne, s. 34 .

S. Tołpa Śladami łosia. Z wędrówek po Polesiu, Zakład Narodowy im. Ossolińskich, Lwów 1936, S. 131.

O wpisanym w antynomię Wschód-Zachód polskim wizerunku Rosji/Rusi - wcieleniu „szatana politycznego", pisała m.in. Maria Janion w esejach Polska w Europie i Ruskie i polskie, w: tejże Niesamowita Słowiańszczyzna, s. 163-256. 
W dwudziestoleciu międzywojennym przekonanie o konieczności pozbywania się rosyjskich pozostałości, naleciałości i wpływów (prawosławie!) było oczywistością, podzielaną przez społeczeństwo polskie i jego elity od prawa do lewa. Nie kwestionowano potrzeby derusyfikacji terenów dawnego zaboru rosyjskiego, w tym postrzeganego jako silnie zrusyfikowane i w związku z tym zacofane - Polesia. Oto wypowiedź Leona Wasilewskiego, piłsudczyka, działacza ruchu prometejskiego, z roku 1936. Wypowiedź typowa dla polskiego dyskursu o Polesiu, bez względu na jego polityczne odcienie:

Polesie nie było przecież puszczą - panowało na nim przez z górą sto lat państwo rosyjskie. Toteż państwo polskie musiało się rozprawić z tą rosyjskością. Ślady tej rosyjskości są jeszcze bardzo silne. W wielu wypadkach Poleszuk nieuświadomiony uważa się - jako prawosławny za Rosjanina. [...] [W] wiosce białoruskiej chłop za swój język kulturalny uważa język rosyjski. [...] Jest to widome nawarstwienie kultury rosyjskiej..$^{56}$

Hydra rosyjskości, której carska postać na Polesiu, w każdym razie z perspektywy optymistycznego dyskursu polonizacyjno-modernizacyjnego, sytuowała się już w przeszłości, aktualizowała się jednakowoż pod nową, współczesną postacią. Jak objaśnia samozwańczy znawca „duszy ludności poleskiej”, wpływowy mitotwórca Ferdynand Antoni Ossendowski, ludność ta była „długo trzyman[a] w ciemnocie przez urzędników rosyjskich i zatruwan[a] wrogą dla Polski propagandą carskiego systemu, a po nim - w równym, a może w większym jeszcze i aktywniejszym nawet stopniu - przez rząd sowiecki”. Trucizna ta przejawiała się m.in. w „kilkuletni[ej] «działalnoś[ci]» band dywersyjnych, złożonych z naiwnych chłopów poleskich, podburzanych przez komunistów"57. W interpretacji autora monografii wsi Czudzin w powiecie łuninieckim, studenta WSH Rudolfa Roleckiego, nie ma mowy o naiwności chłopów; przeciwnie - postrzega się ich jako wyrachowanych:

Agitacja komunistów zdziałała swoje; dziś niemal wszyscy są komunistami. Początkowo mówili głośno o tem, że bolszewicy znów przyjdą i odbiorą ich Polakom. Potem jednak z biegiem czasu zaczęli ustosunkowywać 
się do nowej sytuacji wyczekująco i z rezerwą. W głębi ducha każdy z nich oczekuje przyjścia bolszewików. ${ }^{58}$

O wnioskach wyprowadzanych z diagnozy silnych wpływów komunistycznych na Polesiu możemy przeczytać też m.in. u Pawlaka:

Władze polskie, obejmując tę ziemię, miały na uwadze, że na Polesie wpływały i długo jeszcze wpływać będą różne, nieprzyjazne nam czynniki, szerzące idee odśrodkowe i wywrotowe. Dlatego też rząd polski w stosunku do Poleszuków zastosował specjalną taktykę, polegającą na przywiązaniu ich do Polski, drogą wpajania w ludność tego bagienno-leśnego kraju zdrowego pojęcia jego własnych, żywotnych interesów i wygód. [...] Bodaj najważniejszym zadaniem było uświadomienie i przekonanie Poleszuków, że ziemia, zaludniona przez nich, należy wyłącznie i bezpowrotnie do Polski, która nie ma zamiaru bynajmniej zrzekać się swych praw do tej części Rzeczypospolitej. Z tego zrozumienia wynikło istotne przeświadczenie o konieczności podporządkowania się prawu i państwowości polskiej.59

A więc polityka oswajania dzikusa-Pigmeja „z poleskiej kniei”60/ "polskiej dżungli”. Oswajania przez uświadomienie „ludności tego bagienno-leśnego kraju", co leży w jej żywotnym interesie, bo sama tego nie wie. To jasne: owym najlepiej pojętym własnym interesem jest podporządkowanie się. Silniejszemu. Relacja dominującej większości i podporządkowanej mniejszości jest w polskim dyskursie o Poleszuku wyrażana m.in. za pomocą figury „podnoszenia”. „Podnoszenia” na „wyższy” poziom cywilizacji oraz kultury podmiotu, który najpierw się symbolicznie i faktycznie poniżyło i wyzuło z praw (zauważmy: ich ziemia jest ledwie ziemią „zaludnioną przez nich"). Jak ujął to dyrektor Zakładu Doświadczalnego Uprawy Torfowisk pod Sarnami, Bronisław Chamiec: „Gospodarcze podniesienie Polesia to zbliżenie go do poziomu polskiego i do kultury polskiej. [...]

R. Rolecki Czudzin, wieś powiatu łuninieckiego. Stosunki społeczno-gospodarcze, „Białoruskie Zeszyty Historyczne" 2006 nr 26, s. 211. cze Uczniów Gimnazjum Państwowego im. Marszałka J. Piłsudskiego w Pińsku w 1938 roku. 
Poleszucy marzą o wyrwaniu się z błota poleskiego"61. Ale jednocześnie, jakby uzasadniając cytowane wcześniej przeświadczenie Marczaka o poleskim „niesłychany $[\mathrm{m}]$ prymityw[ie] [...] niedający[m] się podciągnąć"62, dodawał:

Jest jeszcze jeden moment, dla którego niższe nacje niż polska rozszerzają swój stan posiadania [...]. W pojęciu chłopa człowiek kulturalny, pan itp. - to człowiek bogaty. Do tego poziomu Poleszuk nie może się podnieść; toteż Poleszuk przyłączyć się może raczej do poziomu nacji bliższej mu pod względem stanu gospodarczego; może się więc równać z Białorusinem, Ukraińcem itp., podczas gdy Polacy, i tym samym ich kultura, wydają mu się nieosiągalne. ${ }^{63}$

Jednoczesna konieczność i niemożliwość podniesienia Poleszuka z nizin ciemnej i prymitywnej ruskości na wyżyny kulturalnej i cywilizowanej polskości to nierozstrzygalna sprzecznośćc4 $c^{64}$ Ów wewnętrzny pat optymistycznego dyskursu i zarazem projektu modernizacji-polonizacji wiąże się z jego punktem dojścia: nieuchronną klęską, która stanowi logiczną konsekwencję części jego założeń. Założeń definiujących „niższość” i „ruskość” Poleszuka jako jego nieusuwalną - a więc niedającą się „ucywilizować" $\mathrm{i}$ „zasymilować" - esencję. Tkwi on także w odmowie dostrzeżenia - w miejsce konstruktu mającego reprezentować niekatolickich, niepolskojęzycznych, nienależących do kasty panów mieszkańców pogranicza Białorusi i Ukrainy - „Poleszu[ków] z krwi i ciała” ${ }^{\text {. W }}$ odmawianiu mieszkańcom Polesia podmiotowości, czyli poddawaniu ich procesowi „modernizacj[i] przeciw emancypacji"66. W tym, że nie chodziło o Poleszuka; jak zawsze, chodziło

61 Dyskusja po referacie /ózefa Obrębskiego, s. 325.

62 M. Marczak Ze spostrzeżeń nad Poleszukami, s. 134.

63 Dyskusja po referacie /ózefa Obrębskiego, s. 324-325.

64 Bywa ona racjonalizowana, jak np. u Marczaka: „Ciężka jest dola Poleszuka od wielu wieków, a kiedy wreszcie zdawało się, że po zetknięciu się z kulturą będzie mógł swój los poprawić, pokazuje się, że brak na to środków" (M. Marczak Ze spostrzeżeń nad Poleszukami, s. 134).

65 „To, co nam jest dane bezpośrednio, to z jednej strony Poleszucy z krwi i ciała, tacy, jakimi są rzeczywiście i jakich bliżej nie znamy, z drugiej zaś strony istniejące o nich wyobrażenia [...] ich wizerunki" (J. Obrębski Legenda leśnych ludzi, s. 438).

66 E. Janicka O kontrkulturę - tu i teraz, "Recykling Idei” 2016; http://recyklingidei.pl/janicka-o-kontrkulture-tu-teraz (10.04.2017). 
o Polaka. O jego, konstruowany w lustrzanym odbiciu, autowizerunek. Jeszcze raz Obrębski: „Czymkolwiek [...] [Poleszuka] uczynimy - chochołem [...], małpoludem, herosem czy wreszcie (i kiedyż to nastąpi?) zwyczajnym ludzkim człowiekiem, równym nam i nam podobnym - o jednym powinniśmy pamiętać: nie będzie on nigdy w tym powszechnym micie, który o nim utworzyliśmy czy jeszcze tworzyć będziemy, wiernym odbiciem rzeczywistości, lecz wizerunkiem własnym nas samych"67.

Konstytutywnym rdzeniem autowizerunku Polaka jest pozycja dominująca (inaczej: pańskość) wobec społecznych i symbolicznych partnerów. By mogła się wyrażać w postaci symbolicznej i realnej przemocy, musi konstruować jej obiekty. Obiekty pogardy i dyskryminacji: zdegradowane, wykluczone, odczłowieczone. Wobec takich obiektów Polak, „zdominowany przez swą własną dominację"68, może czuć się panem. I zarazem ich realizującym misję cywilizacyjną dobroczyńcą. Trzeba powtórzyć za Elżbietą Janicką: „W tej sytuacji dyskryminacja nie wyraża patologii, lecz normę społeczną, jest stanem pożądanym i moralnie prawomocnym"69.

\section{Bezimienna masa}

Jak wskazał cytowany już Pawlak, Poleszukowi należy uświadamiać, na czym polega jego własne dobro, ponieważ sam sobie tego uświadomić nie umie. Nie jest to tylko perspektywa polskich cywilizatorów działających w okresie międzywojennym: „[a]dministracj[i] polsk[iej], [...] wojska i szkoły, [przy] współprac[y] ludności polskiej osiadłej na Polesiu, [które] wykonały już w tej dziedzinie niezmiernie doniosłą pracę"70. To dawny koncept, logicznie spójny z szerszym dyskursywnym (i faktycznym) spektrum ubezwłasnowolniania mieszkańców Polesia. Z trwałym kolonialno-paternalistycznym ukierunkowaniem polskiego dyskursu o Poleszuku. Najwyższa pora zapytać, czy w związku z tym „Poleszuk” - emblematyczny chłop pańszczyźniany, prymitywne bydlę robocze i ruski dzikus - w ogóle ma pojęcie, kim jest.

67 J. Obrębski Legenda leśnych ludzi, s. 443.

68 P. Bourdieu, L. Wacquant Zaproszenie do socjologii refleksyjnej, przeł. A. Stawisz, Oficyna Naukowa, Warszawa 2001, S. 168.

69 E. Janicka O kontrkulturę - tu i teraz (10.04.2017).

70 W. Pawlak Naród bagienny, s. Vl. 
Kolonialny dyskurs o Poleszuku, jak każdy mit, nie martwi się o własne sprzeczności. Choć swemu obiektowi przypisuje esencjalną ruskość, stale ponawia pytanie - tu w ujęciu Marczaka: „Któż to jest Poleszuk? Jakiej narodowości? On sam tego nie wie i w r. 1931 wpisało się 63\% jego współziomków w odpowiedniej rubryce narodowościowej jako «tutejsi»"11, a więc nie Ukraińcy, nie Białorusy i nie Polacy, choć każda z tych nacyj wpisuje ich na swoje konto"72.

Motyw nieświadomości chłopów poleskich w odniesieniu do własnej tożsamości ma podobnie długą tradycję jak cały dyskurs dehumanizujący Poleszuka. Byli oni już przez dawne autorytety diagnozowani jako „lud bez nazwiska", ergo, dodajmy, również bez historii. W wykładach paryskich stwierdzał Mickiewicz: „Kiedy ludy sławiańskie pograniczne dawno już walczyły, miały wodzów i dawały się poznać cudzoziemcom, na Polesiu siedziały plemiona pobratymcom nawet zaledwie znane, bez wodzów, bez politycznych podziałów, a często bez szczególnych nazwisk"73.

W dwudziestoleciu międzywojennym motyw ten, ubierany w scjentystyczną maskę, dobrze się zestroił z dyskursem rasowym i wzbogacił przy tym o argumenty genetyczno-etniczne.

Dwa miljony Poleszuków oczekuje zatem ostatecznego wyroku o swem pochodzeniu ciemnem i tajemniczem dotychczas nierozwikłanem. Mozolą się nad rozwiązaniem tej zagadki uczeni [...]. Jedni uważają ich za Białorusinów, inni odnoszą ich do grupy małoruskiej. Prawdopodobnie jest to mieszany typ etniczny. ${ }^{74}$

Czy takie projektowanie na dyskryminowanych chłopów stygmatyzującej kategorii "mieszaności” nie służy, obok innych dyskursywnych zabiegów, zmyleniu tropów, by nie wyszło na jaw, że w istocie to nie realni mieszkańcy Polesia nie wiedzą, kim są? Problem z tożsamością konstruktu,

71 Autor tekstu jest w błędzie: spis z 1931 roku nie uwzględniał pytania o narodowość. Zamiast niego formularz spisowy przewidywał pytanie o język ojczysty. Język "tutejszy" zadeklarowało w woj. poleskim ponad 700 tys. osób, tj. $62 \%$ mieszkańców. W powszechnej opinii utrwaliło się (i trwa po dziś dzień) przekonanie, że ta deklaracja dotyczyła (braku) tożsamości narodowej. M. Marczak Ze spostrzeżeń nad Poleszukami, s. 132.

Cyt. za: O. Kolberg Białoruś - Polesie. Dzieła wszystkie, t. 52, Polskie Towarzystwo Ludoznawcze, Wrocław-Poznań 1968, s. 4. 
jakim jest wyobrażony Poleszuk, wpisują wszak w ten konstrukt jego twórcy. W jakim celu?

Skoro ktoś sam nie wie, kim jest i jak się nazywa, można z niego (i z nim?) zrobić, co się chce. Ulepić go podług własnego kaprysu i dla własnych celów. W latach 8o. XIX wieku anonimowy autor „Dziennika Poznańskiego” wyraził, jak się zdaje, powszechne w tej mierze przekonanie polskiej opinii publicznej:

Lud białoruski jest dziwnie dobry i spokojny. Jest to materiał, z którego każdy rząd rozumny mógłby zrobić, co by chciał. [...] Świadomość narodowa w nim nie istnieje, zagadnięty, kim jest, włościanin białoruski zwykle odpowie: „Jo, panoczku, tutejszy”, jak gdyby słowo „tutejszy” było dlań alfą i omegą. ${ }^{75}$

Tę społeczno-kulturową oczywistość wykorzystała politycznie administracja II RP, wprowadzając do drugiego spisu ludności w 1931 roku, wyłącznie na użytek mieszkańców województwa poleskiego, opcję określania tożsamości przez wskazanie języka ojczystego w kategoriach nienarodowych - rubrykę „tutejszy”76. Deprecjonującą funkcję tej kategorii, obok jej teoretycznych inspiracji dla socjologii narodu, dostrzegał Obrębski. „Jak to" - zapytywał ironicznie - „więc ten anonimowy człowiek pogranicza ukraińsko-białoruskiego, figurujący w oficjalnym spisie ludności w niesławnej rubryce «tutejszych »" ${ }^{77}$ ma mieć aż tak wielkie znaczenie dowodowe w kwestiach, dotyczących wielkich współczesnych narodów?"78. Odpowiedź twierdzącą przyniosły

75 „Dziennik Poznański” 1887, cyt. za: O. Kolberg Białoruś - Polesie, s. 38.

Wschodniosłowiańskiemu spektrum językowemu przypisano poza tym cztery opcje, które można było wybrać na terenie całego kraju: ukraiński, ruski, białoruski, rosyjski.

77 Zdaniem Obrębskiego nie była to kategoria emiczna: „Miejscowi [lub] tutejsi jako określenie języka czy narodowości [to] kategoria sztuczna, narzucona ludności - tak jak kategoria «białoruskości» czy «małoruskości» [była] narzucona przez rząd rosyjski" (J. Obrębski Lud bez ojczyzny, W: tegoż Polesie, s. 273]. Wyczerpujące omówienie zagadnienia „tutejszości” w dyskursie naukowo-eksperckim i publicystycznym oraz praktyce politycznej dwudziestolecia międzywojennego przedstawił Piotr Cichoracki w artykule Tak zwani "tutejsi" na Polesiu jako zagadnienie polityczne w Polsce w latach 1921-1939, "Sprawy Narodowościowe” 2013 nr 42, S. 101-113.

78 J. Obrębski Dzisiejsi ludzie Polesia, w: tegoż Polesie, s. 305. I dalej: „We [współczesnym] stanie wiedzy socjologicznej nie zdyscyplinowany, karny i świadomy swego związku ze zbiorowością członek narodu, maszerujący w pierwszych szeregach demonstracji patriotycznej [...], ale właśnie człowiek beznarodowy, bezimienny i bezpostaciowy skupia i musi skupiać na sobie główne zainteresowanie socjologa narodu. Twierdzenie to brzmi jak paradoks. Usprawiedliwia je jednak współczesny stan wiedzy socjologicznej o narodzie, [...] w której brak nawet zgody 
jego materiałowe i teoretyczne studia dotyczące procesów narodotwórczych; w powszechnym obiegu przeważały jednak stare, bezkrytycznie powielane klisze. Jak bezpośredni ciąg dalszy wywodu z „Dziennika Poznańskiego” brzmi późniejsza o pół wieku wypowiedź Tołpy:

[L]ud poleski to masa bierna, która bez pomocy ani kroku naprzód nie postąpi. Lud biedny, a z gruntu dobry i życzliwy. Dotychczas nie widać w nim żadnych aspiracyj poza chęcią chyba poprawienia swego bytu. Ten, kto się nim zajmie, zdobędzie jego zaufanie i ulepi z tej bezkształtnej jeszcze masy to, co zechce. Praca została już podjęta. [...] Nad Polesiem zaczyna się przecierać świt lepszej doli. ${ }^{79}$

Oglądany przez pryzmat polskiej misji cywilizacyjnej na „kresach” Poleszuk-nikt to czysta karta do zapisania, bezkształtna materia do ulepienia ${ }^{\mathbf{8 0}}$. Ulepienia czego? Kogo? Czy wreszcie człowieka, skoro człowiekiem nie jest? Jeżeli człowieka, to jakiego? Czy na obraz i podobieństwo lepiącego, czy może według innego wzoru? Zasadnicze pytanie brzmi zatem: czy z „tutejszego" da się zrobić Polaka? ${ }^{81}$

na temat tak podstawowy i pozornie prosty, jakim powinna [...] być kwestia definicji narodu" (tamże, s. 305-306; podkr. - A.E.).

S. Tołpa Śladami łosia, s. 131.

80 W tych samych kategoriach dyskurs o Poleszuku postrzega go w perspektywie diachronicznej, por.: „[N]a ziemię poleską już od czasów najdawniejszych parły sąsiednie narody, jak Ruś, Moskwa, Litwa i Polska, wywierając przez wieki całe wpływ polityczny, kulturalny i etniczny, urabiając strukturę narodowościową Polesia" (W. Pawlak Naród bagienny, s. Vl; podkr. - A.E.).

81 Taki był polityczny cel, stojący za użyciem w spisie powszechnym kategorii „tutejszości”. Spośród województw wschodnich II RP poleskie uznawano za najłatwiejsze do polonizacji, argument zaś o beznarodowości jego mieszkańców służył uzasadnieniu prowadzonej przez władze polityki asymilacji narodowej. „Już w latach 20. [...] [u]znawano [...], że kłopot z określeniem własnej narodowości przez Poleszuków jest antyrosyjski w wymowie, a więc korzystny dla polskich interesów. W odniesieniu do kolejnej dekady można uznać, że zazwyczaj w praktyce afirmowano «tutejszość» jako akceptowalne podłoże dla pożądanego procesu polonizacji. Przejściowość etniczna Polesia miała ułatwiać ten proces. [...] Radykalna zmiana w ujmowaniu przez administrację problemu grupy «tutejszych» datuje się od początku lat 30. Nie tylko powrócono do tezy, że powinni oni zostać poddani polonizacji, ale uznano, że są wręcz na nią szczególnie podatni. Symbolem tego zwrotu, a także autorem jego uzasadnienia, był [...] Wacław Kostek-Biernacki, który do końca lat 30. stał na stanowisku, że «tutejszość» powinna być traktowana jako jednoznaczna z - choćby potencjalną - polskością" (P. Cichoracki Tak zwani "tutejsi", s. 108, 111). 
Koncept „biernej”, „bezkształtnej” i nieświadomej siebie masy to podstawowa kategoria nacjonalistycznego dyskursu modernizacyjnego. Właśnie na założeniu o „braku wyraźnego oblicza narodowego” wschodniosłowiańskich "mas" chłopskich, które budowało oczywistość uzasadniającą polską dominację i zarazem pozwalało widzieć ją w kategoriach troski, dobroczynności i misji, opierał się polityczny program polonizacji ludności Polesia (i nie tylko) w II RP. Propaganda tej polityki szczodrze korzystała z klisz upowszechnianych przez dyskurs o Poleszuku. Jak w poniższej próbce, w której oprócz "mas" spotykamy i „prymitywizm”, i opozycję niższy - wyższy, i fantazmat nieposzlakowanej, integralnie pozytywnej „kultury polskiej”82. Mówi jeden z aktywnych twórców i wykonawców tej polityki, minister spraw wojskowych, generał Tadeusz Kasprzycki:

[W]schód Polski jest mozaiką etniczną. Obok grup mniej lub więcej wyraźnie się krystalizujących mamy tam masy amorficzne, bierne narodowościowo. Część z nich posiada nawet swoją prastarą prymitywną kulturę, ale obecnie masy te są w poszukiwaniu kultury wyższej. [...] Musimy iść na wschód całą gromadą, tak, jak walczyliśmy o niego zbrojnie, tak samo obecnie musimy tam pracować w czasie pokoju, żeby go całkowicie nasycić kulturą polską i to, co zdobyto mieczem, umocnić przez wartości duchowe i gospodarcze. ${ }^{83}$

Ten kolonialno-propagandowy dyskurs - i spleciona z nim praktyka polityczna - zdaje się optymistycznie zakładać i wierzyć, że „osobliwy typ człowieka bagien i puszczy" ${ }^{84}$, czyli beznarodowy dzikus, da się oswoić: poprzez proces cywilizowania przetworzyć, niechby i przemocą, w Polaka. Stąd, na przykład „fabryk[a], która zmienia [...] leśnych ludzi w najmłodszy proletarjat Europy”85. Dlatego, inny przykład: „już u dorastającej młodzieży, która prze-

82 Janion proponuje koncept „angelizacja Polski”, współzależny z "satanizacją jej prześladowców” (w tej roli występuje oczywiście Rosja), por. M. Janion Niesamowita Słowiańszczyzna, s. 193-194.

83 Przytoczony cytat pochodzi z wywiadu z gen. Kasprzyckim, którego udzielił on czasopismu „Polska Zbrojna" (nr 267, 29.09.1936). Jego istotne fragmenty zostały przedrukowane w publikacji: I Zjazd Naukowy Poświęcony Ziemiom Wschodnim w Warszawie 20 i 21 września 1936 r. Polesie (Sprawozdanie idyskusje), red. S.J. Paprocki, Komisja Naukowych Badań Ziem Wschodnich, Warszawa 1938, s. 98-101, za którą je cytuję. Cytat ze s. 99.

84 F.A. Ossendowski Polesie, s. 20.

85 K. Pruszyński Kiełkowanie na bagnie, s. 107. 
szła przez szkołę, język zawiera 40-50\% polszczyzny. Czy wobec tego za jedno ćwierćwiecze Polesie nie stanie się polskim obszarem gwarowym, takim na wschodzie, jak kaszubski na północy, a podhalański na południu?"86. Także, jak w apologetycznej narracji w trybie faktów dokonanych:

KOP przez samowystarczalność gospodarczą, nowe metody uprawy ziemi stanowi najlepszą szkołę pokazową dla okolicznych Poleszuków. Przyglądają się oni ofiarnej pracy Kopistów, przychodzą do nich po radę i pomoc, uczą się i naśladują. Drugą potęgą, która skutecznie walczy z nieufnością Poleszuków i wpaja w ich dusze idee polskie, stała się szkoła powszechna, ucząc Poleszuków czytać i pisać po polsku i wprowadzając ich w świat wiedzy i kultury polskiej. ${ }^{87}$

Czyż odbiorca tej propagandy sukcesu mógł wątpić, że naród bagienny ${ }^{\mathbf{8 8}}$ rzeczywiście można przekształcić w naród polski?

\section{Prawdziwa natura}

Sprzeczności dyskursu o Poleszuku nie rozpływały się jednakże w pustce. Poleska (pra)materia musiała - ze swej natury - stawiać opór kształtującemu ją Polakowi. Natura esencjalistycznego obiektu jest bowiem niezmienna z definicji. Zaś w głębi natury Poleszuka tkwi immanentna nieoswajalność.

Dlatego motyw „człowieka/ludu bez imienia” musi być i jest semantycznie splątany z innymi cechami wizerunku chłopa-dzikusa: niewolniczą chytrością/przebiegłością („domeną Kaina”) i zwierzęcym brakiem kultury („domeną Chama") ${ }^{89}$.W dyskursywnych realizacjach międzywojennych polskich „poleszukologów” splątanie to występuje w charakterystycznej figurze n i e przyznawania się do tego, kim się jest. Innymi słowy: w postaci insynuacji, że „Poleszuk” - który „posiada charakter nieufny, mrukliwy, mściwy

86 M. Marczak Ze spostrzeżeń nad Poleszukami, s. 132-133.

87 W. Pawlak Naród bagienny, s. VI.

88 Taki tytuł nosi artykuł Wacława Pawlaka.

89 Domena Kaina i Chama to zaproponowane przeze mnie kategorie analizy wizerunku chłopa, sygnalizujące jego mityczną genealogię (por. A. Engelking "Poleszuk” odczłowieczony. O relacji polsko-poleskiej przez pryzmat mitu [w druku]). Por. też: S. Ossowski Struktura klasowa w społecznej świadomości, s. 120-123. 
i nieraz drapieżny"90 - ukrywa swoją tożsamośćp1. W niecnych, co chyba nie ulega wątpliwości, celach. Antypolskich?

W ujęciu niezawodnego Ossendowskiego insynuacja ta brzmi: „nie przyznawali się do żadnej narodowości, a nawet wiary, z uporem powtarzając, że są... Poleszukami"92. W dyskursie quasi-naukowym, przybierającym pozory obiektywności, jak u Pawlaka:

Powszechnie uważa się ich za Białorusinów, lub też łączy się z grupą małoruska. Sami Poleszucy nie przyznają się przeważnie do tych narodowości, podkreślając swą odrębność etniczną określeniem: „tutejsi”. [...] Nie ulega wątpliwości, że pewna część Poleszuków - wobec słabego skrystalizowania poczucia odrębności narodowej - podawała się przy spisie za Rosjan, Białorusinów, Polaków, czy też Ukraińców, wobec czego faktyczna ich liczba jest niechybnie wyższa. ${ }^{93}$

Poleszuk podaje się za kogoś innego: a więc ukrywa się przed Polakiem, kamufluje, maskuje, przybiera inną tożsamość. To nie dziwi - naturę esencjalistycznego Poleszuka cechuje wszak chytrość, przebiegłość, podstępność, oszukańczość, co sprawia, że wraz z esencjalistycznym Żydem sytuują się wśród symbolicznych potomków Judasza ${ }^{94}$. W odniesieniu do Polaka taki rodowód byłby nie do pomyślenia.

Optymistyczny wariant dyskursu nacjonalistyczno-modernizacyjnego, kontynuujący oświeceniowo-pozytywistyczny paradygmat „oświecania ludu", zakładał, że przednowoczesna dzika zwierzyna - inaczej: gotowa do rzezi "kozaczyzna” - przekształcona w indyferentną narodowo masę, podda się z czasem procesowi uczłowieczania. Czyli: zasymiluje do polskości. To złudny optymizm. Wystarczy bowiem byle impuls, byle pretekst - i oto bierna masa pokazuje kły i pazury. Mamy bowiem przed sobą „mieszkańców bagien i puszcz [...] ni to łoś - nieufnych, ni to ryś - drapieżnych, zawsze

F.A. Ossendowski Polesie, s. 147.

Drugi wariant: ciemny i prymitywny, nie chce wiedzieć, kim jest: „Od blisko stu lat pop wbija mu w głowę, że «mużyk» jest prawosławny i to przekonanie tubylcowi wystarcza" (M. Marczak Ze spostrzeżeń nad Poleszukami, s. 135).

F.A. Ossendowski Polesie, s. 74.

W. Pawlak Naród bagienny, s. VI.

Por. A. Engelking „Poleszuk” odczłowieczony. 
tajemniczo milczących, jak olbrzymie ryby zlewiska dnieprowego, a w porywie rozpaczy i gniewu - wściekłych i groźnych, jak niedźwiedź, z barłogu zimowego zruszony"95. Nie łudźmy się: bierność jest tylko maską dzikości ${ }^{96}$. Wrogiej dzikości.

Czyżby za dzikim zwierzęciem i nierozumnym bydlęciem - nieczłowiekiem, który nie wie, kim jest - majaczył ktoś „uzbrojony nożami”97? A noże, wiadomo, można wbić w plecy. Polakowi. „Ileż to podświadomych, we krwi pozostałych wspomnień działa tu nieprzerwanie, to słabnąc, to znów wybuchając z nową siłą i popychając do czynów rozpaczliwych lub szalonych. $\mathrm{Na}$ każdym tu kroku czają się cienie pradziadów [...], szepcą o gwałcie strasznym i zemsty żądają od prawnuków" ${ }^{98}$. Czyż może więc zaskakiwać, że „[w] głębi ducha każdy z nich oczekuje przyjścia bolszewików"99?

Jakże więc kogoś (coś?) takiego włączyć do polskości? Okazuje się, że można próbować - pod warunkiem, że obiekt polonizującego eksperymentu przestanie być Poleszukiem. Esencjalistyczną nadzieję na to zdawała się dawać jego „domieszka krwi sarmackiej”. Poleszuk jednak - na mocy swojej natury - pozostawał mieszańcem. Był - bo taki był dyskurs o nim - ambiwalentny. Może i garnął się do polskości, ale nie przestawał być nieufny. Może się i polszczył, ale - był ruski. Nacjonalistyczny dyskurs polonizacyjno-modernizacyjny, maskujący przemoc tradycyjną frazeologią paternalizmu i nowoczesną narracją postępu, oscylował między strategiami „zwabić i oswoić" a „okiełznać i zdławić". Przesmyk między nimi był tak wąski, że prawie niedostrzegalny.

Prawdziwa, dzika natura Poleszuka pozornie oswojonego może bowiem obudzić się w każdej chwili. By do tego nie dopuścić, należy ją zdławić. Zdławić w Poleszuku ruskiego i bolszewika. Ale jak tu zdławić czyjąś prawdziwą naturę? Chyba tylko przez eksterminację. Jak pokazała niewiele późniejsza

F.A. Ossendowski Polesie, s. 151.

Przykład dyskursu polskiej charakterologii narodowej dotyczącego Rosji: „Jak przedtem była bierność zastoju, niezdecydowania, nieświadomości, tak pod rządami bolszewików objawiła się nowa forma bierności - bierność niszczenia i przelewu krwi, ślepego okrucieństwa i barbarzyńskiej dzikości. Zawsze ta sama bierność, apatyczna, ciemna, nierozwiniętego narodu" (J. Parandowski Bolszewicy i bolszewizm w Rosji, 1919, cyt. za: M. Górny Wielka Wojna profesorów, s. 94).

97 J. Weyssenhoff Pamiętnik generała Jana Weyssenhoffa, s. 16.

98 F.A. Ossendowski Polesie, s. 28.

R. Rolecki Czudzin, wieś powiatu łuninieckiego, s. 211. 
historia, nie jest to niemożliwe. Taką próbę podjął choćby „Bury”, dokonując czystki etnicznej w prawosławnych wsiach Białostocczyzny.

"Bury” i jemu podobni sądzą, że do czystego Polaka droga wiedzie przez czystkę. Z pozoru logiczne, rozumowanie to wiedzie prosto do zguby: „czysty” Polak egzystuje bowiem tylko dzięki Innym, których uprzednio skonstruował i wyprojektował, by móc w opozycji do nich konstytuować własną czystość. Anihilacja Innego musi więc prowadzić do anihilacji Polaka. By „Polak” mógł istnieć, musi wytwarzać swojego „Poleszuka”, na analogicznej zasadzie, jak wytwarza swojego „Żyda”. Wytwarzać po to, by móc wykluczać z polskości.

\section{Poleszuk wykluczony}

Reprezentujący polskie państwo i polską kulturę cywilizator i polonizator musiał, wskutek przemożnej siły nieuświadomionych wzorów kultury, dochodzić do wniosku, że Poleszuk nie tylko był, ale też jest i pozostanie Poleszukiem $^{\mathbf{1 0 0}}$. Jego nieredukowalna nieoswajalność to bowiem w ostatecznym rozrachunku nic innego niż antypolskość. Fakty przekonywały o słuszności tego wniosku: w polskiej polityce wobec wschodniosłowiańskich mniejszości w latach 30. narastała przemoc. Obrębski, obserwując i analizując te procesy, konstatował pojawienie się w stosunkach polsko-poleskich "koncepcji wroga narodowego"101. W jego pismach czytamy: „Chłop oczom polskiego inteligenta i półinteligenta, polskiego pana i podpanka, objawiał się tutaj nie jako swój, ale jako obcy, wróg panów polskich i wróg państwa; i nie w krakowskiej sukmanie, nie z dekoracyjnym pawim piórem u polskiej rogatywki, ale [...] z nieodłącznym kołtunem na głowie"102. Reguła ta musiała działać w obie strony. Formował się i poleski stereotyp wroga: „Wrogami chłopa stają się już nie «pany», definiowani w kategoriach klasowych, lecz «Polaki», naród panów i podpanków, w których - zgodnie z tradycyjnymi wyobrażeniami Lacha-ciemięzcy - upatruje Poleszuk sprawców swoich krzywd i aranżerów hniotu, to znaczy ucisku"103.

100 Zasadę tę dosadnie wyraża znane przysłowie: Smaruj chłopu dupę miodem, będzie zawsze śmierdzieć smrodem.

101 J. Obrębski Dzisiejsi ludzie Polesia, w: tegoż Polesie, s. 313.

102 J. Obrębski Pańska szkoła i mużyckie dzieci, s. 353.

103 J. Obrębski Dzisiejsi ludzie Polesia, s. 294. I dalej: „Wykształcony w tej sytuacji wizerunek Polaka ma dla niektórych tak negatywną wartość, że epitet polaczok uważany jest za bezczestie" [tj. zniewagę]. A w innym miejscu, o procesie narodotwórczym na Polesiu: „ukazuje nam [miano- 
Jak wiemy od Bourdieu, nie ma dominacji bez wykluczenia. Dlatego ostatecznie polonizacja Poleszuka nie jest możliwa. Poleszuk, uwewnętrzniony-wykluczony Inny, pełniący obok Żyda funkcję konstytutywnego obcego etnonacjonalistycznego modelu polskości, jest więc Polakowi niezbędny, by ten mógł istnieć i trwać jako Polak. Niezbędny na zasadzie dokładnie przeciwnej niż zasilający „rezerwuar polskości” Krakowiak.

Polski dyskurs o Poleszuku - jedna z odmian polskiego dyskursu dyskryminacyjnego i zarazem istotny nurt polskiego dyskursu kresowego - demonstruje, że ruscy chłopi, przodkowie współczesnych Ukraińców i Białorusinów, dobrze znani polskiej tradycji jako dzicz, czerń i bydło, nie mają i nie mogą mieć w sobie nic z Piasta. Poleszuk musi pozostać nieoswojony, czytaj: wykluczony z polskości. Wykluczony podwójnie: jako chłop (dzikus bez kultury) i jako ruski (prawosławny, chochoł, bolszewik). Tego domaga się, jak ujęła to Elżbieta Janicka, polska „wspólnotowa rama społeczno-kulturowa, na którą składają się: doksa etniczno-religijna i doksa antykomunistyczna"104. I tego, konsekwentnie, domaga się konstruowany w tej ramie, wokół różnicy narodowej i klasowej, narcystyczny autowizerunek Polaka-pana. Widać go, na wylot i bez reszty, $\mathrm{w}$ „nieuświadomionym i wiernym odbiciu” figury „Poleszuka”.

wicie te] podstawowe sytuacje, w których dochodzi do wytworzenia się postaw negatywnych w stosunku do narodu państwowego. Chodzi tu o formowanie się postaw antagonizmu i krystalizowanie poczucia odrębności, mającego swoją przyczynę w istniejących obiektywnie różnicach wzorów kulturalnych. [Postawy te formują się] w trwałe myślowe wzory: w koncepcję wroga i trwałe subiektywne uprzedzenia grupowe - stereotypy i mity społeczne, przeprowadzające granicę między swoimi i obcymi niezależnie od obiektywnie istniejących różnic" (tamże, s. 294, 317-318). 


\section{Abstract}

\section{Anna Engelking}

THE INSTITUTE OF SLAVIC STUDIES, POLISH ACADEMY OF SCIENCES

The Untamed 'Poleshuk': The Role of the Peasant in the Construction of Polishness

Engelking examines the representations of the Poleshuks (the people of Polesia) in mainstream Polish culture. Based on selected examples of popular writing from the interwar period, Engelkind portrays Russian peasants - the ancestors of today's Ukrainians and Belorussians - as an emblematic figure of Polish discourses of the Borderlands. The stereotypical notion of the Poleshuk is based on concepts drawn from race theory, nationalist and colonial discourses as well as modernizing ambitions, and it is an internalized and at the same time excluded Other. Like the Jew, the Poleshuk functions as a constitutive foreign ethno-nationalist model of Polishness. The Poleshuk is excluded from Polishness in two ways: as a peasant (a savage with no culture) and as a Russian (Orthodox, Bolshevik). It is the narcissistic self-image of the Pole as the higher ranking'lord' (pan) that requires this image of an untamed and untameable'Poleshuk' as its obverse constructed on national and class-based difference.

\section{Keywords}

postcolonial studies, Polish colonialism, discourses on the Borderlands, stereotypes of the peasant, Polesia 